\title{
Ulcerative Colitis and Colorectal Cancer: Challenges and Opportunities
}

\author{
Siddhartha Kumar Mishra* \\ School of Biological Sciences, Dr. Harisingh Gour Central University, India
}

Submission: February 10, 2017; Published: February 28, 2017

"Corresponding author: Siddhartha Kumar Mishra, Cancer Biology, School of Biological Sciences, Dr. Harisingh Gour Central University, Sagar-470003, India, Tel: +91-7582-265004; Email: siddharthakm@yahoo.com

Keywords: Inflammation; IBD; Ulcerative colitis; Colorectal cancer; Wnt/ $\beta$-catenin; NF-кB

\section{Editorial}

Inflammatory bowel disease (IBD) is chronic inflammatory disease affecting approximately 1.4 million people in the United States. IBD comprises mainly two disorders, ulcerative colitis (UC) and Crohn disease (CD). UC is restricted to the colon and rectal segments, while $\mathrm{CD}$ is a variable disorder. $\mathrm{CD}$ may affect essentially any segment of the gastrointestinal tract, with a preference for the terminal ileum [1]. UC is caused by an abnormal immune response by body due to mistaken identity food, bacteria, and other materials in the intestine for foreign or invading substances by immune system. This leads to recruitment and influx of immune cells in intestinal epithelial cells causing chronic inflammation and ulcerations. While UC causes mucosal inflammation, $\mathrm{CD}$ is associated with granulomatous features and transmural inflammation that can be complicated by intestinal wall fibrosis and stenosis, internal and external fistulas, and intra-abdominal infections. Irrespective of the IBD subtypes, the involvement of the colon and rectum and chronic inflammation leads to increased risk for colorectal cancer (CRC) [1]. Although patients with colitis-associated cancer (CAC) represent only about $1 \%$ of CRC cases, colitis patients are at highest risk of CRC [2]. Patients with prolonged ( $>20$ years) and extensive colitis have even higher $(20 \%)$ risk of CRC development. Furthermore, a certain subset of patient with inflammation in the biliary tract featuring primary sclerosing cholangitis have an even greater (50\%) lifetime risk of CRC [2].

CRC, also known as bowel cancer, is cancer of colon and rectum. It is the second most common cancer worldwide, after lung cancer. CRC is highly spread in the US probably due to dietary and living habits with about 1 in 20 people in the US will developing CRC. CRC may be benign or malignant. CAC represents only a small fraction of the overall burden of CRC.
The molecular pathogenesis of CAC is mainly inflammationassociated carcinogenesis [3]. CRC is mostly due to lifestyle factors include diet, obesity, smoking, and lack of physical activity. The other major risk factor for CRC is IBD. Certain inheritable genetic disorders are also the major causes of CRC especially familial adenomatous polyposis and hereditary non-polyposis colon cancer yet their ratio is less than $5 \%$ of total CRC cases. CRC is a disease originated from the epithelial cells lining the colon or rectum of the gastrointestinal tract. Aberrant mutations in the Wnt signaling pathway increases CRC induction and progression signaling activities. These mutations are inherited or acquired and may occur in the intestinal crypt stem cell [4]. APC is the most commonly mutated gene in CRC. This produced APC protein which prevents the accumulation of $\beta$-catenin protein. When APC is absent (or mutated), $\beta$-catenin accumulation is multifold high and it translocates into the nucleus. Inside nucleus, $\beta$-catenin binds to DNA and activates the transcription of proto-oncogenes mainly cMyc and Cyclin D1 [4]. These gene expressions favor cell cycle and proliferation in aberrant manner causing stem cell renewal and differentiation. Along with Wnt signaling pathway, mutations in other genes like p53 make a worsen disease scenario [3]. Furthermore, proteins responsible for programmed cell death are generally deactivated in CRC such as TGF- $\beta$ and DCC (Deleted in Colorectal Cancer). TGF- $\beta$ has a deactivating mutation in at least half of CRC, as well as a downstream protein named SMAD is also deactivated [3].

Connecting the epithelial cell inflammation and cancer induction, another major key player is nuclear factor NF- $\kappa B$ which nearly always activated in mucosa under IBD condition [5]. NF- $\kappa \mathrm{B}$ is a pleiotropic transcription factor with a key role in innate and adaptive immunity $[5,6]$. NF- $\mathrm{KB}$ is a key player in 
CAC whose function is regulated by NF- $\kappa B$ inhibitors that may prevent its nuclear accumulation and DNA binding [5,6]. The $\mathrm{NF}-\kappa \mathrm{B}$ activation dynamically regulates various cellular stimuli including proinflammatory cytokines, microbial products, and various forms of cellular stress including DNA damage [6]. NF- $\kappa B$ is essentially required for the expression of various proinflammatory factors such as proinflammatory cytokines and chemokines and adhesion molecules in CRC [5]. An animal model of CAC induced by azoxymethane and dextran sulfate sodium (AOM/DSS) has shown dramatic activation of NF- $\mathrm{B}$ in the intestinal epithelium causing tumor multiplication by enabling the role of NF- $\mathrm{BB}$ signaling in CAC [7]. NF- $\mathrm{KB}$ activation in the immune compartment is important for tumor growth which has trophic effects on the outgrowth and/or progression of neoplastic colon cancer cells probably via over expression of certain cytokines such as IL1 $\beta$ and IL-6 [7]. Thus, blockade of NF- $\kappa \mathrm{B}$ can ameliorate or prevent the development of colitis and CRC and that this has been a therapeutic approach in several studies. We have recently reported that an aqueous extract of edible mushroom chaga (Inonotus obliquus) and its ergosterol peroxide caused down regulation of $\beta$-catenin and NF- $\kappa B$ signaling in human colon cancer cell lines and in intestinal inflammation and CRC in animal models [8-10]. Thus, a recent attention has shifted in CRC management by regulating $\beta$-catenin and NF- $\kappa B$ signaling pathways by using natural products because of their lesser side-effects as compared to conventional antiinflammatory therapies.

In conclusion, UC and CRC are resultant of chronic inflammation in mucosal and epithelial cells due to aberrant activation of immune cells. A recent trend in managing this inflammatory is by suppressing inflammation pathways and tumor growth signaling such as NF- $\mathrm{B}$ and Wnt/ $\beta$-catenin signaling. These two signaling can be targeted by multiples agents from synthetic sources to natural products.

\section{References}

1. Boland CR, Luciani MG, Gasche C, Goel A (2005) Infection, inflammation, and gastrointestinal cancer. Gut 54(9): 1321-1331.

2. Itzkowitz SH, Harpaz N (2004) Diagnosis and management of dysplasia in patients with inflammatory bowel diseases. Gastroenterology 126(6): 1634-1648.

3. Markowitz SD, Bertagnolli MM (2009) Molecular origins of cancer: Molecular basis of colorectal cancer. N Engl J Med 361(25): 2449-2460.

4. Bienz M, Clevers H (2000) Linking colorectal cancer to Wnt signaling. Cell 103(3): 311-320.

5. Andresen L, Jorgensen VL, Perner A, Hansen A, Eugen-Olsen J, et al. (2005) Activation of nuclear factor kappaB in colonic mucosa from patients with collagenous and ulcerative colitis. Gut 54(4): 503-509.

6. Hacker H, Karin M (2006) Regulation and function of IKK and IKKrelated kinases. Sci STKE 2006(357): re13.

7. Greten FR, Eckmann L, Greten TF, Park JM, Li ZW, et al. (2004) IKK beta links inflammation and tumorigenesis in a mouse model of colitisassociated cancer. Cell 118(3): 285-296.

8. Kang JH, Jang JE, Mishra SK, Lee HJ, Nho CW, et al. (2015) Ergosterol peroxide from Chaga mushroom (Inonotus obliquus) exhibits anticancer activity by down-regulation of the beta-catenin pathway in colorectal cancer. J Ethnopharmacol 173: 303-312.

9. Mishra SK, Kang JH, Song KH, Park MS, Kim DK, et al. (2013) Inonotus obliquus suppresses proliferation of colorectal cancer cells and tumor growth in mice models by down regulation of $\beta$-catenin/NF- $\mathrm{KB}$ signaling pathways. Eur J Inflamm 11: 615-629.

10. Mishra SK, Kang JH, Kim DK, Oh SH, Kim MK (2012) Orally administered aqueous extract of Inonotus obliquus ameliorates acute inflammation in dextran sulfate sodium (DSS)-induced colitis in mice. J Ethnopharmacol 143(2): 524-532.

\section{Your next submission with JuniperPublishers will reach you the below assets}

- Quality Editorial service

- Swift Peer Review

- Reprints availability

- E-prints Service

- Manuscript Podcast for convenient understanding

- Global attainment for your research

- Manuscript accessibility in different formats

( Pdf, E-pub, Full Text, audio)

- Unceasing customer service

Track the below URL for one-step submission https://juniperpublishers.com/online-submission.php 